\title{
Mark Twain and Sigmund Freud on the Discontents of Civilization $\cdot W$. R. Irwin
}

THE FRAMERS OF THE American Declaration of Independence asserted that human beings have certain inalienable rights-life, liberty, and the pursuit of happiness. These founding fathers might have declared also that "in a stare of nature" only the powerful, predatory few can enjoy these rights. For most people life in that mythic state would be, as Thomas Hobbes describes it in Leviathan (1650), "solitary, poor, nasty, brutish, and short." In a word, uncivilized. Our forefathers might have noted further that the only releases from this dismal condition are two fortunate developments of mythic history: the forming of a social contract and the growth of civilization. They might finally have declared what experience teaches us, that the price of our happy civilized state is the curtailment of personal freedom.

We easily evade these simple, self-evident, bitter truths, for our candor is a feeble security against self-deception. We must rather rely on people whose gift to us is the steady reminder that the price of pleasure is pain. Such benefactors were Mark Twain and Sigmund Freud.

I propose to show that, in their different ways, Mark Twain and Freud gave concentrated attention to the conflict between personal freedom and culture. Neither could perceive any happy resolution. The best that any person can achieve is compromise and endurance. ${ }^{1}$ Even those who try to reject society by seeking solitude and detachment-those who "light out for the territory"- - have before them no congenial prospect.

Now there is nothing original in the conclusions I have been sketching. Students of culture, even those who reject license and exalt liberty within the law, who claim that the benefits of civilization are worth the cost, or who hold social order to be a manifestation of divine will, have never been able to deny that civilization generates discontents. That the discontents can be scorned as unworthy, overcome by piety, argued into quietude by self-deception does not make them less real. Civilization requires an internalized control of the aggressiveness which is, as Freud

${ }^{1}$ Freud seems to hold out a hope that in some vague future the harshness of the cultural superego will be mollified by some kind of therapeutic control. How this may affect individual happiness he does not suggest. (Civilization and its Discontents), translated . . and edited by James Strachey (New York: Norton, 1962, p. 91.) 
notes, "the constitutional inclination of human beings ... towards one another."

I need not continue stating the obvious. Rather I turn to the ways, remarkably similar, in which two persons, remarkably dissimilar, saw the problems and dealt with them. Most of you have already surmised that for this examination I shall concentrate on two books: The Adventures of Huckleberry Finn and Civilization and its Discontents.

A useful approach may be through some consideration of Mark Twain and Sigmund Freud themselves. At first sight it may seem that the two had little in common. Mark Twain, born and reared along the Mississippi River before the Civil War, when the civilizing process was in an early stage and only the river towns showed signs of what is usually thought to be culture. Mark Twain, with little formal education, self-made by enterprise, adventure, travel, personally directed reading, but never remotely an intellectual in the usual sense of the word. Mark Twain, journalist, professional funnyman driven by need and later by debt to more performance than he found comfortable, a commentator who relied for his validity on acute observation, a curious combination of tolerances and prejudices, and his sense that human nature is everywhere and at all times essentially the same, "the damned human race." Freud, a Jewish intellectual, heir to an old and highly wrought culture scorned by those who did not share it, an urbanite in that most urbane of cities, Vienna, at a time when its urbanity was at a height of flourishing decadence, with disaster not far in the future. Sigmund Freud, carefully and systematically educated in long-established disciplines, which he mastered and from which he then seceded, driven by an experimental, questioning, speculative mind to clinical determinations and principles of therapy which members of his profession long resisted. Sigmund Freud, polymath, citizen of Europe, stimulator of disciples and cults as well as of opponents, promoter through no wish of his own of myriad popularizations and endless cocktail party conversations, provided as much by those who do not understand his work (perhaps have not even read it) as by those who do, arbiter still of our assumptions as to personality.

How could any two men be more different? Yet many of you have detected even in the contrasting generalizations I have just proposed, ways in which the two minds and dispositions were similar. Both were born humbly, to decent stock, but with no privilege of family ascendancy. Both were self-made, struggling through early hardships, never 
enjoying affluence. Both propounded iconoclastic views. Both found little comfort in their inherited religions. Both were devoted family men, though Freud's adjustment to this demand of civilization seems to have been more comfortable than Mark Twain's. Both were capable of great, though unsentimental, compassion with the insulted and the injured of their worlds; both scorned pettiness and malice. Both attracted admirers, even disciples, and in their different ways left impressions on cultures beyond those of their immediate spheres of action, impressions which are visible today. If the personages of history have some power to make us what we are, we owe part of our present being to Mark Twain and Sigmund Freud.

Let us come a little closer and examine more specific evidence of rapport between them. It is a matter of record that Freud was well acquainted with the works of Mark Twain. He attended one of the "public readings," in Vienna in February 1898. Freud mentions this event in a letter to his friend Dr. Wilhelm Fliess: "I treated myself to listening to our old friend Mark Twain in person, which was a great pleasure." Years later he cites the same experience in a footnote to a passage in Civilization and its Discontents. Predictably enough, Freud countered repeated assertions that the psychoanalytic movement is dead by quoting Mark Twain's famous telegram: "Report of my death greatly exaggerated." In response to an inquiry from the Viennese publisher Hugo Heller, Freud names Mark Twain's Sketches among ten "good" books: books "to which one stands in rather the same relationship as to 'good' friends, to whom one owes a part of one's knowledge of life and view of the world-books which one has enjoyed and gladly commends to others, but in connection with which the element of timid reverence, the feeling of one's own smallness in the face of their greatness, is not particulary prominent." ${ }^{3}$ Along with Mark Twain's Sketches, Freud mentions other books. Among them are Kipling's Jungle Book, the Essays of Thomas Babington Macaulay, and Merezh-Kovsky's Leonardo da Vinci. It is altogether a strange list, which, in accordance with the spirit of the request, has "come to my mind without a great deal of reflection." But the list does show again the catholicity of Freud's tastes in reading, for it becomes evident, in the brief essay which he

${ }^{2}$ See The Origins of Psychoanalysis: Letters to Wilhelm Fliess, Drafts and Notes: 1887-1902 (New York: Basic Books, 1954), p. 245. Ernest Jones dates the lecture as September 2, 1898, a mistaken reading perhaps of 9. 2. 98. See The Life and Works of Sigmund Freud, 3 vols., (New York: Basic Books, 1957), 1, 329. Jones, 3, 422. 
wrote to accompany his reply, that he knew the "great books," the "significant books," and his own "favorite books" as well. Indeed, one wonders again why Freud did not choose literature, rather than medicine, as the major emphasis in his versatile career.

In Jokes and the Unconscious Freud cites several stories by Mark Twain, all of which in some way illustrate the reliance of humor on "economy of pity." That these stories concerning his family or his brother, are transfers or fabrications only heightens the comic effect. For example, "... Mark Twain presents us his pedigree, which he traces back almost as far as one of the companions of Columbus.... The mechanism of humoristic pleasure is not disturbed by our knowing that this family history is a fictitious one, and that this fiction serves a satirical tendency to expose the embellishments which result in imparting such pedigrees to others; it is just as independent of the conditions of reality as the manufactured comic." ${ }^{4}$ Of course, Freud's comments on Mark Twain's humor illustrate all over again that casual analysis of comic effects are usually as dreary as the comic itself is lively. But they show also an abiding respect for Mark Twain's work.

Of course, no one should be surprised at Freud's allusions to Mark Twain, in contexts both personal and professional. The Vienna master is famous for his range, for finding clinical clues in non-clinical sources. Even so, his attention to Mark Twain, in the citations above and in other passing allusions which I need not mention, suggests more than a casual acquaintance and regard.

When we look, however, in the works of Mark Twain and in his copious autobiographical writings for references to Freud, there is only silence. It is no good to say that Mark Twain must have read Freud because of the ease with which purposeful people can discern Freudian hints in his fiction or because in a series of stories written after his daughter Susy died Mark Twain exploited dream motifs. The interpretation of dreams for purposes of diagnosis and therapy was scarcely within his capability. Actually, circumstances alone would make it unlikely that Freud could have come more than by accident to Mark Twain's notice. His trips to Europe in the late nineteenth century were scarcely culture cruises; he was lecturing for money, exploiting his reputation in order to pay his debts. His discovering a revolutionary depth psychol- 
ogy would have been only a remote possibility. Even if he had discovered it, and-even more amazing-understood it in its unpopularized, untranslated form, he would surely have felt prudentially obligated to stay clear of any such scandalous speculations, however congenial he might secretly have found them.

Mark Twain died in 1910. Freud's one visit to America occurred in 1909, when he delivered five lectures at Clark University and received an honorary doctorate, the only such award of his lifetime. Freudianism for non-professionals reached America later, indeed, not before 1915, and it became a matter for sophisticated conversation in the 1920's. ${ }^{5}$ Even had he been disposed to such a subject, Mark Twain had virtually no chance to become acquainted with it.

So, despite the repeated allusions to Mark Twain in Freud's work, the engaging prospect of exchange between the two who were great in disparate ways was never a real possibility. Whatever else, this essay cannot be a study of influence or reciprocal profit. Even so, a substantive congruity of the two men's views on civilization and its discontents is discernible, and to this I now turn.

I shall lead with a brief discussion of Civilization and its Discontents. Early in Chapter 3 Freud states the problem, mentions a solution which, though appealing, is patently unworkable, and shows that the human dilemma imposed by civilization is such that no prompt solution can be expected. A remarkable achievement for these two sentences:

This contention holds that what we call our civilization is largely responsible for our misery, and that we should be much happier if we gave it up and returned to primitive conditions. I call this contention astonishing because, in whatever way we may define the concept of civilization, it is a certain fact that all the things with which we seek to protect ourselves against the threats that emanate from the sources of suffering are part of that very civilization. (p. 33)

From this the conclusion he reaches may be expected: "My intention has been to represent the sense of guilt as the most important problem

${ }^{5}$ On the spread of Freudianism in America see Frederick J. Hoffman, Freudianism and the Literary Mind (Baton Rouge: Louisiana State University Press, 1957), pp. 44-58. Rose Macaulay's novel Dangerous Ages (New York: Boni and Liveright, 1921) shows psychoanalysis of Freudian orientation already well established in England and high-level popular accounts of Freudian theory already fashionable reading among the bright young people. 
in the development of civilization and to show that the price we pay for our advance of civilization is a loss of happiness through the heightening of the sense of guilt" (p. 81). Actually throughout the short book Freud deals with other matters of importance, but all are related to the conclusion he presents. He does not wish to "express an opinion upon the value of human civilization" (p. 91). His conscience and his professional habits force him to limit his considerations to a description which he derives from a speculative history of the psyche during the time it is learning conformity with the demands of civilization.

Repeatedly he states that all his revelations are no more than common knowledge, and I doubt that this is a pose of ironical modesty. After we have read the book it does seem to state what is common knowledge, though few of us could write anything like it.

Let me attempt to trace the history of the psyche as it learns and forces itself to meet the demands of civilization. Freud seems implicitly to agree with those political mythographers who posit that some time in the far past, the majority of persons living in a "state of nature" found themselves needing protection from the predatory power of the few. So, by a concerted act, they created the "social contract," and with their unified strength forced the powerful few to accept it. One dare not be more specific here, for one is dealing with an aetiological myth which has even less narrative substance than most myths of national heritage. Several consequences of the contract came along in time. It took human advantage of, though it did not directly achieve, the taming of fire, the use of tools, the development of technology, accomplishments fostering the institutions which organize religious experience, education, domestic living, the arts. These institutions are the agents of social amelioration, and they secure to man the "beauty, cleanliness, and order" which he needs as much as he needs control of the forces and resources of nature.

Even before these phenomena of civilization gained the development which we know, any person born into the new dispensation faced problems with the demands of civilization and with himself. Even now, it is axiomatic that no one is born civilized and that no one becomes civilized by such a conversion as that which transformed Saul of Tarsus into Saint Paul. The social contract is already there, and each person must get through a process, slow, effortful, never completely successful, of meeting its demands. There are the sexual drives, which are far from simple-not just predatory and aggressive, not just cherishing and 
nurturing. Eros is prominent, but Pan and Priapus are there as well. Clearly it is no good to eliminate the problems deriving from the libido simply by unselective, or even selective, castration. Clearly no external control will work to minimize the aggressive potential of sexual desire while maximizing its power to promote communities of love. Most of the institutions which develop have some program to this end, but unless people are to lose all freedom and with this all capability of contributing to the growth of civilization, institutional control of the id is infeasible. What is needed is internal control, in a word, conscience or superego, derived from the ego itself, but endowed with a power to inspire fear which, internalized, becomes that great monitor, a sense of guilt, a phenomenon different, as Freud points out, from remorse. All institutions must operate to keep the sense of guilt effective in controlling the barely latent aggressivity of each person, because only when this sense of guilt is keen can the positive, beneficial, elevating results of cultural institutions be achieved. So we have the civilized person-unable to escape civilization; surrounded by its benefits and demands; pleased with them, perhaps aspiring to advance the good works of culture, but still plagued by anti-cultural urges; wishing to be virtuous, but aware that, if virtue gives no other reward than its ineffable self, the reward is poor indeed. Throughout all these ambivalences, the civilized person remains guilt ridden, restive, discontented. What is true of the person is true also of the societies, even the "primitive" ones, which seem at sight to have none of the problems of civilization. As it is with sex, so with all other kinds of energy. Repression is essential, if man is to survive and prosper, and guilt, that internal agent of repression, is our best friend. But, stubbornly human, we not only love, we also hate our friend. Somewhat as I have described Freud's book is in general the way Mark Twain would have understood it, had he enjoyed the opportunity to read it. ${ }^{6}$

Now we know that, for whatever reason, the works of Mark Twain are free of any representation of genital love, heterosexual or homosexu-

${ }^{6}$ Though Mark Twain was innocent of Freudian language, he understood that conscience, which we have come to know as a substructure of the superego, dwells on violations of our ideals and promotes feelings of guilt. An excellent example is his fantasy entitled "The Facts Concerning the Carnival of Crime in Connecticut." In this Mark Twain's own conscience, a "shriveled shabby dwarf" which nonetheless resembles him, appears to torment him with his sins of omission and commission. This "caricature of me in little" is censorious, gleeful, malicious, and right. "Every sentence was an accusation, and every accusation a truth." And when Mark Twain kills the little monster, he exults: "You behold before you a man whose life-conflict is done, whose soul is at peace, a man whose heart is dead to sorrow, dead to suffering, dead to remorse; a man without a conscience." Thereafter he launches on a carnival of crime, and his "life 
al. Much as he may have been amused by the genteel tradition, it had him in its grip. But as I suggested earlier, the history of the psyche's adjustment which Freud traces in terms of sexuality, because this is fundamental, may be traced also to essentially the same uneasy peace in the other aspects of the individual's confrontation with the blessings and the unwelcome demands of civilization. And with many of these non-sexual aspects of civilization and its discontents Mark Twain dealt copiously in Huckleberry Finn. Moreover, he sets forth in narrative some features of the conflict which Freud, for good reason, only hints at. Freud was concerned with the theoretical aspects of a basic and permanent problem. It was not to his purpose in the work we are considering to present specific social anatomy and even less to indulge himself in value judgments. Mark Twain, however, was concerned with social anatomy, and he had the experience on which to base accurate descriptions and narratives. He was indeed interested in value judgments which, though they show no vanity of dogmatizing, are nonetheless partisan, sometimes favoring and sometimes opposing standard values. Particularly, because he was devoted to his idea of the damned human race, he was intent to show how official proponents of civilization can be the most flagrant enemies of civilization, even when they are presumably acting without animus against it. Mark Twain was also much interested in human maturing, how it can be both advanced and impaired by one of the great institutions of civilization, education.

In the paragraphs to come I shall examine first what we learn about education in Huckleberry Finn and then what we see of offenses against civilization as perpetrated by civilized people themselves.

From many works other than Huckleberry Finn we know that Mark Twain held a plenitude of views about the discontents of civilization and those who have made it. But Huckleberry Finn itself is bare of formulary and theoretical statements. Even so, from character, events, and dramatic presentation we can reliably infer a critique, mostly adverse though

is all bliss." (See Tom Sawyer Abroad, Tom Sawyer, Detective, and other Stories (New York and London: Harper, 1924, pp. 302-325).

In this jeu d'esprit Mark Twain ignores the ego-ideal, that counterpart of conscience, and fails to distinguish between remorse and feelings of guilt. Even so, Mark Twain reveals perceptions and convictions remarkably consonant with Freud's.

I am grateful to my colleague Professor Baender for suggesting that the fantasy discussed in this note is pertinent to the subject of my paper. 
comically expressed, of the institutions designed to keep society in order.

Let us start with the main character himself. In the view of those who surround him, except for Jim, Huck Finn is a bright youngster desperately in need of civilization. On the first page we learn that "the Widow Douglas she took me for her son, and allowed she could civilize me ..." In their different and sometimes strange ways others have the same motivation-Miss Watson, Judge Thatcher, Aunt Sally, Tom Sawyer. All work by some kind of attempted direct imposition. Huck Finn's own attitude is ambivalent. He is grateful, knowing, somewhat like the young James Boswell, his own need to lead an orderly life. Huck is existentially guilty, susceptible and compliant, respectful of authority, yet restive and resistant. To complete the sentence quoted earlier: "But it was rough living in the house all the time, considering how dismal regular and decent the widow was in all her ways; and so when I couldn't stand it no longer I lit out." This part of the sentence is, I propose, a purposeful forecast of the last two sentences in the book: "But I reckon I got to light out for the territory ahead of the rest, because Aunt Sally she's going to adopt me and civilize me, and I can't stand it. I been there before." Does this envelope of language mean that Huck has learned nothing from the educative process of his adventures? Scarcely. In fact, he has improved his natural shrewdness and competitiveness to the point of being capable of any kind of worldly success he might wish. It does mean, I believe, that Huck Finn has seen the moral issues in that unequal contest between personal freedom and conformity which Freud describes and has made his choice of values. On the islands, on the raft, by himself or in Jim's company, Huck Finn experiences moments of blissful freedom. The two of them do indeed form, in Lionel Trilling's happy phrase, a community of saints. But these moments are always succeeded by confrontations with aspects of civilization, elevated or corrupt, which abrogate the simple enjoyment of release and make Huck defend his personal values as best he can. In such defense he is remarkably skillful. But still his maneuvers are responses to social pressure, not actions freely taken, and thus they are compromised.

There are in the preceding paragraph several threads which I did not follow out. I excepted Jim from the company of those who attempt to civilize Huck Finn. Yet Jim does more than anyone else to educate him, to promote an acceptance of certain aspects of being civilized, aspects which are both unorthodox and valid. Jim's secret of effectiveness is one 
which he himself does not know. He educates, not by imposing programs derived from institutions, but by submission and love. He can reproach, as he does after Huck plays the mean trick of making Jim believe that he was only dreaming on the fogbound raft, and thus he prompts, not guilt, but what Freud calls remorse. But this reproach, coming from disappointed love, is powerfully effective. Probably more than anything else, this incident determines Huck's decision at that time of moral crisis when he tears up the note to Miss Watson and consents to go to hell. Here we see the real force of Jim as unintending teacher: his example, not his effort, draws out from Huck the best that worthy youngster has in him. There are, of course, passages, mainly comic, in which Jim and Huck attempt to instruct each other-Huck as a purveyor of enlightenment as to French and history, Jim as expositor of the reality and value of superstition. But these have none of the marks of imposed civilizing. They do not show a "superior" person bestowing benefit on an "inferior." There is no effort on the part of either to secure conformity; they are not coercive. Likely Huck does benefit by coming to understand superstition, an understanding which no enlightened person dare neglect. But again it is an understanding which he freely accepts. In short, the efforts to civilize Huck by imposing education on him produce little benefit, except to sharpen his native shrewdness and make his resistance more effective. From teacher Jim, however, he gains something far better than knowledge. He gains a brother, an inestimable satisfaction for a boy who has always been lonely, and he gains a mature moral sense.

Huck Finn's other encounters with civilizing forces are less happy than his dealings with Jim. What he learns from watching the institutions which civilize and by feeling their pressure on himself is exactly what Freud noted, that by repressing personal freedom they generate a discontent from which there can be no lasting relief, for the discontent is, in effect, the price that civilization exacts from each of us. And Huck learns something further, a truth implicit in Freud's essay, though Freud does not stress it. Grant that there can be no civilization without the exertion of a superior power, usually embodied in an institution, on persons who must be made and kept obedient. If the obedient submit, so that there need be no evident coercion, all seems harmonious; the institution and its agents appear benevolent, perhaps actually are. But, as Huck Finn sadly observes, there is nothing inherent in a civilizing institution to prevent its agents from using it to advance their personal 
interest by coercing and exploiting the unprotected, much as they did in the mythical "state of nature." Now let us see in more detail what Huck Finn observes of the workings of civilization.

Any genuine civilization is a social organism, a complex of many elements. The main components of civilization which Huck Finn sees, in addition to education, are organized religion, law (chiefly the law of property), the differentiation among persons as to social standing, and the conventions of inherited romance. He sees both benign and destructive manifestations of each. He cannot avoid participating in the operations of each and being affected by each. Huck's participations are sometimes admirable, sometimes culpable, though the general tendency of his character development is toward maturity and improvement. Huck encounters religious people throughout his adventures, and his attitude toward them and their professed beliefs is not at all simple. He knows they are mainly benevolent towards him, and he knows that he needs their beneficence, which, in fact, he gets from most of them. But he knows that every one of these pious people derives from religious belief a conviction opposed to freeing a slave, understood as a piece of property the possession of which is protected by law. Huck Finn shares this conviction with such intensity that when he violates it, he assumes that he has chosen damnation. But his love for a new-found brother makes him willing to accept the eternal punishment. As Freud tells us, love is the most forceful civilizing emotion, though he might have added that attempts to institutionalize love make up a generally sorry history.

We all know that established majority religions and secular law are for worldly purposes normally in accord. Both yield rules for daily conduct. Embarrassment and worse arise when a religiously founded counter code, derived from such unworldly values as love and justice, comes into conflict with a religiously founded code for prudent and advantageous daily conduct. So Huck Finn is far worse than embarrassed to obey the inner prompting which tells him that his black brother Jim has an inherent right to be free. What Huck chooses is the kind of action which, generally practiced, might give us that yet unknown phenomenon, the good society, good according to the ethical code of any of the world's major religious faiths. Without having read the preface to Androcles and the Lion, Huck knew the truth of Shaw's pronouncement:

This man Jesus has not been a failure yet; for nobody has been 
sane enough to try his way. ... We have always had a curious feeling that, though we crucified Christ on a stick, he somehow managed to get hold of the right end of it, and that if we were better men we might try his plan... ${ }^{7}$

Somewhat naively we assume that the more civilized people are, the higher will be their social position, their standards of conduct, and their prosperity. Huck Finn has grown up accepting all this as axiomatic and believes as a consequence that his own low status is a result of his unworthiness, for which he feels guilty. Exactly as Freud suggested, Huck Finn's guilt is his internalized response to social pressures. He longs to resemble his "betters"- the Widow Douglas, Tom Sawyer, Judge Thatcher, and others - though he understands too that all of them are in some way short of ideal beings. The ugliness of anti-civilization he sees chiefly in his drunken father. So he forms a naive division of people into good and bad, civilized and uncivilized, before he begins his quest down the river. But on that journey he encounters two shocking demonstrations of how uncivilized civilized people can be. I refer, of course, to his experiences while he is a guest, almost an adopted son, of the Grangerfords, and to the murder committed by Colonel Sherburn. In both narratives there is vivid exemplification of what Freud posits as that aggressiveness which expresses the death instinct against Eros, the life instinct and maker of civilization. And in both narratives the principal aggressors are ostensibly civilized people. Mark Twain is careful to detail the excellence of his whole prosperous, socially elevated Grangerford family in a portrait of the patriarchal Colonel:

Col. Grangerford was a gentleman, you see. He was a gentleman all over; and so was his family. He was well born, as the saying is, and that's worth as much in a man as it is in a horse, so the Widow Douglas said, and nobody ever denied that she was of the first aristocracy in our town; and pap he always said it, too, though he warn't no more quality than a mudcat himself. ... He was as kind as he could be-you could feel that, you know, and so you had confidence. Sometimes he smiled, and it was good to see; but when he straightened himself up like a liberty-pole, and the lightning begun to 
flicker out from under his eyebrows, you wanted to climb a tree first, and find out what the matter was afterwards. He didn't ever have to tell anybody to mind their mannerseverybody was always good-mannered where he was. Everybody loved to have him around, too; he was sunshine most always-I mean he made it seem like good weather. When he turned into a cloud-bank it was awful dark for half a minute, and that was enough; there wouldn't nothing go wrong again for a week. ${ }^{8}$

An admirer of civilization, Huck finds the entire world of the Grangerfords, as he first sees it, congenial beyond belief. But he has not yet heard of the feud. When he does, his education is rapidly advanced, first by a conversation with Buck, who outlines the rationale of a feud, and then by the skirmish which ends with Buck shot down. Huck has learned one lesson as to how civilization can tolerate a barbarism which a simple barbarian could not match.

Very soon he learns another, when Colonel Sherburn kills the drunken Boggs and then faces down a lynching mob. This incident is more briefly told than that of the feud. Since the two seem to make the same point, one wonders why Mark Twain included the second at all. One may guess that the two incidents illustrate two ways in which justice and order, two benefits of civilization, may be perverted by civilized people. The feud, a private guerilla war, has its own justice and order, understood by all participants. An apologist might say that the feud harms only Grangerfords and Shepherdsons, all of whom, except for Harney and Miss Sophia (the Romeo and Juliet of this piece), accept its conditions. An adverse critic might say that the harm spreads far wider, for the killings rob a needful society of potential leaders. But any resolution of these conflicting views is left to the reader's inference.

To draw conclusions about perverted justice from Colonel Sherburn's savage act and its consequences is still an operation of inference. But these may be clearly drawn. Here a man is murdered for no worse action than offensive conduct. Boggs is no part of the feud, and one can regrettably guess at the deranged notion of personal honor Colonel Sherburn is vindicating. But what force of law and order exerts itself to punish this murderer? Only a spineless mob, which can be rendered impotent by the contempt and bravado of one criminal. We never hear 
of any effort to arrest, indict, try and punish the patently guilty Colonel Sherburn. Socially privileged and officially civilized, he goes free, thereby frustrating what Freud notes as "the first requisite of civilization ... the assurance that law once made will not be broken in favor of an individual." Colonel Sherburn shows us, as do others in the book, what Freud asserted in The Future of an Illusion, that "every individual is virtually an enemy of civilization, though civilization is supposed to be an object of universal human interest."

Between these two incidents Huck Finn is introduced to the first of two other exposures to abuses of civilization fostered by its very values. First he and Jim must endure for what seems an intolerable time the antics of the Duke and the Dauphin before their final ignominious reward. Soon thereafter begins the long and often censured account of "rescuing" Jim, as stage-managed by Tom Sawyer.

Before examining these sequences, however, let me state another widely accepted assumption. Civilization and high, often snobbish, culture, not only go together but also by reciprocal action elevate each other. So Huck Finn admires the achievements of cultured people, and again he regards his uncultured state as the necessary concomitant of his unworthiness. He never understands, even at the end of the story, that in his way he is as accomplished culturally as the best of those whom he encounters. Huck Finn is impressed by the amenities, as well as by the abundant good food, of the Grangerford household. He can no more understand than can the Grangerfords that their cultural values and accomplishments, including Emmeline's poetry, would be a joke or a cause of sorrow to any one possessed of conventional sophistication. In the Duke and the Dauphin, however, and later in the antics Tom Sawyer directs as they "rescue" Jim, Huck Finn sees perversions of the already mentioned alliance of civilization and cultural performances. Again, as with the two sequences of killing, we have a complementary pair of exposures, with Huck Finn undeceived through both, though he does not exert himself to end the follies.

The cultural values misused by the Duke and the Dauphin and then by Tom Sawyer derive from the conventions of romance, as these were imported from Western Europe into the raw and yet dependent United States, an importation for which Mark Twain made Walter Scott bear a burden of blame. Ignorant as they are, the Duke and the Dauphin know just enough of these conventions to understand that the yokels find them impressive and cannot at first detect the frauds perpetrated in their 
name. This sequence, then, shows the exploitation possible through cultural fakery, for in the prosperous period before they end their ascendancy tarred and feathered on a rail, the Duke and the Dauphin live in a fraud's paradise.

No moral opprobrium and no vengeance by outraged victims attend the rescue of Jim, supervised by Tom Sawyer, according to what he understands of the romantic escapes which he associates with Baron Trenck, Casanova, Benvenuto Cellini, and Henry IV, three of whom did describe escapes in their autobiographies. Tom Sawyer, it is clear, has done a powerful amount of reading, and from his insatiable credulity has fixed on principles as delusionary as those which possessed the uneducated Catherine Morland in Jane Austen's Northanger Abbey. But the worst that Tom Sawyer can be accused of is folly and self-indulgence. From the beginning both Huck Finn and Jim appraise the situation realistically, and though they protest the excesses, they do not actively rebel. The reader may be disappointed that they only protest, never resist, Tom's foolishness. The fact is that, except when they deal with themselves and each other, neither one is a forceful moral agent, a strange failing when one considers that as moral perceptors they are both quick and accurate. Huck Finn speaks for both as he assures the reader that he properly dealt with the Duke and the Dauphin as with frauds: "If I never learnt nothing else out of pap, I learnt that the best way to get along with his kind of people is to let them have their own way" (p. 102). Scarcely the policy one might expect from a member of a community of saints. Should we simply reproach Huck and Jim for constitutional moral laxity and a strategy founded on expedient cynicism? I think not. What we really have here is another crippling effect of civilization. So habituated is Huck Finn (and presumably Jim too) to believing that because he lacks the authority which being civilized bestows, he has a right only to perceive privately, but not to act upon others. Huck Finn cannot understand that, being highly civilized, he more than deserves an authority which he never thinks of asserting. The result of all this is an impairment, not of his moral sense, but of his moral energy. Repeatedly he shows himself capable of feelings consistent with charity. He sees the Duke and the Dauphin getting at last that rough justice which their offenses deserve: "Well, it made me sick to see it; and I was sorry for them poor pitiful rascals, it seemed like I couldn't ever feel any hardness against them any more in the world. It was a dreadful thing to see. Human beings can be awful cruel to one 
another" (p. 180). It is hard to imagine a higher degree of civility, without any hint of self-righteousness, than these sentiments reveal. Ignorant of moral theology, Huck Finn knows that part of the doctrine of charity requires that, though one should abhor the sin and understand that punishment is deserved, one sins himself if he abhors the sinner. Are we to reproach Huck Finn and Jim because they rarely convert their attitudes into actions bearing on other people? No. Such is the power over them of the alleged superiority which Tom and others gain from being cultured and civilized that they dare not assert their good sense against conduct which is ridiculous or inhumane, or both. What Huck Finn and Jim perceive, as well as any reader who is not so besotted as Tom Sawyer, is exactly what the members of the Scriblerus Club in the eighteenth century noted about the dunces, that from the sources they imitated they could adopt only the tricks and devices, while failing to understand the principle which gives these devices unity and meaning. The result of such an assembling of fragments is a folly in itself and a violation of culture's essential unifying power.

I would be mistaken, of course, were I to treat the sequences involving the capers of the Duke and the Dauphin and the rescue of Jim as if they were narratives as realistic as the story of the Grangerford-Shepherdson feud. It is impossible to believe that Mark Twain intended or supposed that his readers would perceive any such uniformity of verisimilitude. If there is the discordancy of narrative intentions which some readers have found in the final chapters of Huckleberry Finn, it is introduced, not with the campaign to rescue Jim, but with the intrusion of burlesque and gross comedy in Chapter 19, less than halfway through the book, when the Duke and the Dauphin first come aboard the raft. From that point on believable and fantastic narration are mixed together, with no overt attempt on Mark Twain's part to provide transitions or to resolve them into a single system of credibility. And the reader needs no such help. For he is in approximately the same situation as that presented by Don Quixote, in which repeatedly the credible and the incredible fuse in narrative sequences. A reader must be a purist to find this objectionable, for what Cervantes sought was not a system of verisimilitude such as Defoe and Dreiser repeatedly achieve, but rather a system of true knightly morality, embodied in the mad nobility of Don Quixote, whom Freud also cites in Jokes and the Unconscious as a figure of fun at first who becomes an embodiment of the highest morality. We cannot grant Tom Sawyer the dignity which we give to Don Quixote, for 
Tom's devotion to the values of romance is self-indulgent. But the means of revealing the two, through narrative which mingles the realistic and the fanciful, are essentially the same.

Thus Mark Twain conducts Huck Finn and the reader through a series of demonstrations of the satisfactions and discontents, the uses and abuses, of civilization. He emphasizes the discontents and abuses, as befits an author in the moralistic tradition of comedy, more concerned with exposure than with congratulation. There is nothing perceptibly comic about Freud's essay, but he too is concerned with the exposure and also with causation, the latter of which does not engage Mark Twain's interest, for he is content for explanation with the "damned human race." It is an index of Mark Twain's urbanity, however, that he can make the damned human race seem at times amusing, at times depraved, at times both.

As I noted earlier, Freud restricted his consideration of the causative factors in the forming of civilization and the personal discontents inevitably generated to what can be explained by psychoanalytic theory. Thus he omitted discussion of specific social manifestations and any intimation of value judgments. Let no one think I am reproaching Freud for failing to complete his task. This would be to reproach him for omitting what he never intended to do, for, as a theoretical scientist, he felt obligated to stay within the confines of demonstrable theory and confirmatory evidence. But Mark Twain was writing a story and could scarcely have avoided, even if he had wished to, specific social manifestations. It seems likely also that, despite a direct-and too ostentatiousdisavowal, he is also providing the reader the narrative material from which to infer moral judgments. Moreover, though Mark Twain does not give us a systematic history of Huck Finn's attitudes toward civilization, we do see in the young man a progression remarkably like what Freud describes, the emergence of ambiguous feelings toward the cultural institutions he must face, and, even more, the dominance over him of a maturing conscience, which makes him feel guilty. Guilty of what? As with most of us, nothing except being our own ordinary, aggressive, retrograde selves. And this sense of guilt is what keeps us civilized, as Freud eloquently shows. The only thing Mark Twain omits is what we expect him to omit-any sign of sexuality in any character. To be sure, throughout Mark Twain's narrative and the moral judg- 
ments which it supports there is no hint of a theoretical concern with civilization. But evidently he is deeply concerned with civilization as it bears on persons and societies in daily action, and wishes his readers to share his concern.

By this time I should think that my conclusion is obvious. Different and alike as the two men were, their books are complementary. It is as if they had agreed that what understanding one omitted the other would provide. Among the many sad accidents of cultural history is that the two of them never met. I believe that they would have found each other congenial, compatible in their dispositions, their insights, their sense of comedy, and their tempered sorrow that the human condition in a state of civilization is not, and probably never can be, happier than it is. 